\title{
Constitutional land law: Mexfield and the 40-shilling freehold
}

\section{Document Version}

Accepted author manuscript

Link to publication record in Manchester Research Explorer

\section{Citation for published version (APA):}

Roche, J. (2015). Constitutional land law: Mexfield and the 40-shilling freehold. In W. Barr (Ed.), Modern Studies in Property Law (Vol. 8, pp. 287-305). Hart Publishing .

\section{Published in:}

Modern Studies in Property Law

\section{Citing this paper}

Please note that where the full-text provided on Manchester Research Explorer is the Author Accepted Manuscript or Proof version this may differ from the final Published version. If citing, it is advised that you check and use the publisher's definitive version.

\section{General rights}

Copyright and moral rights for the publications made accessible in the Research Explorer are retained by the authors and/or other copyright owners and it is a condition of accessing publications that users recognise and abide by the legal requirements associated with these rights.

\section{Takedown policy}

If you believe that this document breaches copyright please refer to the University of Manchester's Takedown Procedures [http://man.ac.uk/04Y6Bo] or contact uml.scholarlycommunications@manchester.ac.uk providing relevant details, so we can investigate your claim.

\section{OPEN ACCESS}




\title{
Constitutional land law: Mexfield and the 40-shilling freehold
}

\author{
Juanita Roche*
}

\section{INTRODUCTION}

In Mexfield Housing Co-operative Ltd v Berrisford, ${ }^{1}$ the UK Supreme Court accepted the submission that there was an ancient rule of common law which had been forgotten for nearly a century yet remained binding. The alleged rule was that tenancies stated to determine only on the occurrence of an uncertain event must be deemed, 'automatically', to be tenancies for life, subject to earlier determination on that event; the rule applied no matter what, on construing the relevant agreement, the parties could reasonably be held to have intended. ${ }^{2}$ This rule was said to have been stated in Bracton in the thirteenth century but most clearly by Littleton in the fifteenth and Coke's commentary on Littleton in the seventeenth century, and to have remained good law down to 1925; the court relied particularly on one nineteenth-century textbook, one textbook from 1920, and two nineteenth-century cases. ${ }^{3}$

Against the existence of such a rule, the Supreme Court had before it Zimbler $v$ Abrahams. ${ }^{4}$ In Zimbler, the Court of Appeal held, in 1903, that a particular tenancy agreement expressed to be terminable only on the occurrence of an uncertain event was an agreement for a determinable life tenancy, on ordinary principles of interpretation of that agreement. The Supreme Court in Mexfield said that Zimbler's

\footnotetext{
* University of Manchester. I am grateful to Martin Dixon, Stuart Jones, John Mee, and Matthew Harding for comments on earlier drafts, and to the anonymous referees; all faults remain my own. ${ }^{1}$ [2012] 1 AC 955. Mexfield is generally viewed as being about the alleged rule that a lease must have a fixed maximum term. This paper will not deal with that aspect, for which see eg J Roche, 'The madwoman in the attic: freeing landlord-tenant law' [2011] Conv 444, KFK Low, 'Certainty of terms and leases: curiouser and curiouser' [2012] MLR 401.

${ }^{2}$ Mexfield (n 1) eg 958F, [44], [93], [117].

${ }^{3}$ ibid [39]-[41]; the judgments were Doe d Warner v Brown (1807) 8 East 165 and In re Carne's Settled Estates [1899] 1 Ch 324.

${ }^{4}[1903] 1 \mathrm{~KB} 577$.
} 
ratio was 'wrong', solely because Zimbler did not apply (nor mention) the alleged ancient rule. $^{5}$

However, neither the textbooks nor the judgments relied on by the Supreme Court actually support the alleged rule, which I will call 'the Mexfield rule'. In particular, in neither of the two judgments relied on was the Mexfield rule part of the ratio, nor in either case was there a record of any submissions putting forward such a rule. This raises an obvious question: Had the Mexfield rule ever been relied on as ratio, or even asserted in submissions, in any case?

The answer appears to be no-except that something similar to the Mexfield rule emerges in disputes about qualification for the vote between 1832 and 1884 . Further, this proposal of something like the Mexfield rule, and its popularisation as an argument, were associated particularly with one individual; and, as soon as the court had the chance to consider the proposed rule, the court rejected it, consistently, and adopted as ratio the same approach as in Zimbler.

Analysing this incident leads us into a largely unexplored part of the history of land law. ${ }^{6}$ It is widely known that, down to the twentieth century, there were property qualifications for the vote in England. There were actually also property qualifications for many other forms of participation in the state, from jury service to being a tax commissioner; and these were overwhelmingly qualifications in terms of interests in land. The relationship between possession of particular sorts of interests in land and the constitution of the state ended, in historical terms, only recently-its last vestige, the property requirement for jury service, was not swept away until $1972 .^{7}$ As late as 1888, Maitland, in his lectures on the constitutional history of England, said that 'we

\footnotetext{
${ }^{5}$ Mexfield (n 1) [44].

${ }^{6} \mathrm{cf}$ the dearth of research on the law on electoral process: C Morris, Parliamentary Elections, Representation and the Law (Hart 2012) 2.

${ }^{7}$ Criminal Justice Act 1972, s.25; cf JH Baker, The Oxford History of the Laws of England, Vol VI: 1483-1558 (OUP 2003) 353.
} 
[must] begin our survey of public law by examining' land law, as 'even now it is impossible for us fully to understand our modern public law unless we know something of our law of property ${ }^{8}{ }^{8}$ However, even by 1888 , this constitutional role of land law 'seem[ed] strange', 9 and Maitland's focus on the medieval and early-modern periods foreshadowed a modern assumption that any relationship between land law and the state, other than the one-way traffic of statute affecting land law, was confined to a very distant past. In fact, as will be seen, land law and the state had their most direct and reciprocal engagement in the nineteenth century.

I use the term 'constitutional land law' primarily in a very simple sense: to refer to those aspects of land law which for centuries were literally part of the constitution - part of how the state was constituted - in that they determined who could formally participate in the state. However, the persistence of this simple practical relationship over centuries seems likely to have generated a more complex relationship between ideas of the constitution and doctrinal land law. ${ }^{10}$ This paper is primarily concerned with solving one aspect of the puzzle of Mexfield, but the solution reveals clear resonances between the nineteenth-century legal argument over the Mexfield rule's precursor and contemporaneous ideas of the constitution.

The first section outlines the system of property qualifications for the vote from 1430 to 1884 , two views of the justification for property qualifications, and the procedure by which disputes concerning these qualifications were decided. Second, the 'Littleton rule'- the rule the Supreme Court in Mexfield thought it was applying - is explained, as is a particular problem for that rule in relation to property qualifications for the vote. The third section introduces James Manning and places

\footnotetext{
${ }^{8}$ FW Maitland, The Constitutional History of England (CUP 1908) 23.

${ }^{9}$ ibid 23.

${ }^{10} \mathrm{cf}$, on the genuine and subtle interaction between legal and political ideas, M Lobban, 'The Politics of English Law in the Nineteenth Century', in P Brand and J Getzler (eds), Judges and Judging in the History of the Common Law and Civil Law (CUP 2012) 102-137.
} 
him in the legal and political world of the time; and the fourth section describes his proposed variation of the Littleton rule in the context of property qualifications, and how he promoted his argument. The fifth section describes the court's response, in a series of cases from 1844 to 1879 , against the backdrop of controversy over franchise reform and two different views of the nature of the constitution. Finally, I propose one answer and two questions.

\section{PROPERTY QUALIFICATIONS AND PROCEDURE TO 1884}

The history of qualifications for the parliamentary franchise in the UK is far more complex than most people realise: it was only the Representation of the People Act 1948 which finally produced a relatively simple system of adult suffrage, by ending plural votes for university graduates and occupiers of business premises. ${ }^{11}$

But, in crude terms, and considering only England and Wales and, for the moment, the period before 1832, there were three different types of parliamentary franchise. From 1603, the universities of Cambridge and Oxford each elected their own members of parliament, and all MAs of each university could vote. ${ }^{12}$ Then there were the boroughs, towns and cities which had been made parliamentary constituencies in past centuries; the borough franchise was enormously varied. Finally, there were the counties. The county franchise had been formally uniform since 1430: due to concerns about corruption and disorder in county elections, the vote was restricted by statute to those with a freehold interest in land of a yearly value

\footnotetext{
${ }^{11} \mathrm{C}$ Turpin and A Tomkins, British Government and the Constitution (7th edn, CUP 2011) 51; T Oppermann, 'Universitätsvertretung im britischen Unterhaus 1603-1950' (1957) 113 Zeitschrift für die gesamte Staatswissenschaft 314.

${ }^{12}$ A Thrush, 'Cambridge University', in A Thrush and JP Ferris (eds), The History of Parliament: the House of Commons 1604-1629, vol 2 (CUP 2010).
} 
of 40 shillings or more. ${ }^{13}$ This was even in 1430 a modest value threshold ${ }^{14}$ and became ever lower in real terms as it was never revised: at least by the seventeenth century 'those at the bottom end of the scale would be cottagers or labourers' ${ }^{15}$

The petition on which the statute of 1430 was based described those to be excluded from the franchise as 'de null valu' - translated as 'without property', but literally 'of no value'; ${ }^{16}$ this points toward one tradition of thinking about property qualifications, described as late as 1885 as being 'the modern theory, that Property as such ... is entitled to representation. ${ }^{17}$ But there was another strand of thought, as far back as the fourteenth century, which emphasised the elector's duty to vote for a member of the House of Commons on behalf of the community as a whole, as opposed to the Lords, each of whom, in the words of a fourteenth-century source, 'comes for his own individual self to parliament'. ${ }^{18}$ In this tradition, as Blackstone influentially put it, 'The true reason of requiring any qualification, with regard to property, in voters, is to exclude' those whose situation was such that they could 'have no will of their own', who would be unable to resist pressure from the 'great' and the 'wealthy' to vote in those individuals' interests. At least in the existing state of society, it was necessary that those who 'are under the immediate dominion of others ... are excluded from voting, in order to set other individuals, whose wills may be supposed independent, more thoroughly upon a level with each other., 19

\footnotetext{
${ }^{13}$ See generally SJ Payling, 'County Parliamentary Elections in Fifteenth-Century England' (1999) 18 Parl Hist 237.

14 ibid 244.

${ }^{15}$ D Hirst, 'The Seventeenth-Century Freeholder and the Statistician: a Case of Terminological Confusion' (1976) 29 Econ Hist Rev 306, 310.

${ }^{16}$ Payling (n 14) 244.

${ }^{17}$ WR Anson, 'The Reform Bill' (1885) 1 LQR 25, 27.

${ }^{18}$ Payling (n 14) 238-240.

${ }^{19}$ W Blackstone, Commentaries on the Laws of England (Bk 1, Clarendon Press 1765) 165; cf W Treanor, 'The Original Understanding of the Takings Clause and the Political Process' (1995) 95 Colum L Rev 782, 818-855.
} 
It was always clear that a freehold interest in land could mean many more things than a fee simple; a huge range of interests were capable of being freeholds. ${ }^{20}$ Saliently, life tenancies were always understood to be freeholds. On the other hand, studies of actual constituencies show a 'widespread lack of clarity' as to what exactly constituted a freehold; in practice, the question of whether or not someone had a freehold interest in land, such as to qualify him for the vote, seems to have been primarily a matter of local understandings. ${ }^{21}$

The main reason for this lack of clarity was that, down to 1832 , disputes as to a voter's qualification could only be decided after a contested election and could not be decided in the ordinary courts. ${ }^{22}$ For much of English history and large parts of the country, uncontested elections were the norm. ${ }^{23}$ It was widely believed that there ought to be informal assessment and agreement as to who should represent the constituency, such that a contested election represented a failure-even, in an early nineteenth-century opinion, a manifestation of 'Original Sin. ${ }^{24}$

If there were a contested election, people who believed themselves entitled to vote just turned up at the polls. If some were turned away, or some who were believed not to be qualified actually voted, this could only be challenged by a petition to Parliament challenging the result of the election, and the petition would be decided by a committee of the House of Commons. ${ }^{25}$ These committees did not consider themselves bound by precedent and often lacked legal expertise; put more bluntly, by

\footnotetext{
${ }^{20}$ FSP Wolferstan, Rogers on Elections, Election Committees, and Registration (10th edn, Stevens \& Sons 1865) 21-27.

${ }^{21}$ D Hirst, The Representative of the People? Voters and Voting in England under the Early Stuarts (CUP 1975), 7, 34-42.

${ }^{22}$ See generally C Morris, "From "arms, malice, and menacing" to the courts: disputed elections and the reform of the election petitions system' [2012] LS 226.

${ }^{23}$ D Beales, 'The Electorate before and after 1832: the right to vote, and the opportunity' (1992) 11

Parl Hist 139; P Salmon, Electoral Reform at Work: Local Politics and National Parties, 1832-1841 (Boydell Press 2002) 124 fn 28.

${ }^{24}$ Quoted in F O'Gorman, Voters, patrons, and parties (Clarendon Press 1989) 113.

${ }^{25}$ For details of the election-petition system down to 1868 , see Morris 'From "arms, malice, and menacing"' (n 23) 232-240.
} 
an early nineteenth-century commentator, 'nine-tenths of the House of Commons are hopelessly and incurably incompetent to the decisions of legal questions, and ... more than the suspicion of wilful partiality attaches to their judicial eccentricities. ${ }^{26}$ So the decisions on petitions as to whether a particular interest in land was a freehold were difficult to reconcile.

The First Reform Act, the Representation of the People Act 1832, famously expanded the franchise; in the counties, the main effect was that, for the first time, some tenants other than for life and some copyholders got the vote. ${ }^{27}$ But the Act also introduced voter registration. Roughly, the process in the counties was that, every year, unless they were already registered and their qualification was unchanged, would-be voters had to submit a claim to be registered, including a brief description of the property and the interest in it by which they claimed to be qualified. ${ }^{28}$ The draft lists would then be made public, and anyone could submit an objection to any name on the list. The burden of proof was then on the claimant to prove his qualification, before a new sort of judicial officer created by the Act, a 'revising barrister', who would hold hearings in the constituency.

Under the 1832 Act, appeals from revising barristers' decisions went to Parliament, ${ }^{29}$ but the Parliamentary Voters Registration Act 1843 redirected these appeals to the Court of Common Pleas. Thus by 1844 there was a straightforward means to have disputes as to an individual's qualification, a mechanism to ensure that such disputes were decided by lawyers, and a route by which such disputes could

\footnotetext{
${ }^{26}$ C Neate, 'A Few Parting Words to the Election Committee of 1838', quoted in (1838) 2 The Jurist, No 77 page 1 (anonymous and untitled review).

${ }^{27}$ See Salmon (n 24) 253-254; Anson (n 18).

${ }^{28}$ For this and what follows on the registration process under the 1832 Act, see Salmon (n 24) 20-21, 31-32.

${ }^{29}$ By s.60 of the Act: ibid 30 fn 84 .
} 
enter the ordinary legal system — creating, for the first time, an opportunity to build up a consistent body of law.

Despite the fact that after 1832 a broader range of interests in land gave a qualification to vote in the counties, disputes about the nature of a freehold remained important due to the difference in qualifying values for different interests. Remember that 40 shillings equals $£ 2$. After 1832, in the counties, holders of leases other than for life got the vote only, depending on the length of the term, where the land had an annual value of $£ 10$ or more or the annual rent was $£ 50$ or more; the Second Reform Act, in 1867 , made the value threshold for leases of 60 years or more $£ 5$ a year and introduced a qualification for occupiers of property with a rateable value of $£ 12$ or more. ${ }^{30}$ By comparison, it has been estimated that a family on median income, in 1860 , would if renting be paying a rent of around $£ 8$ per year. ${ }^{31}$ Thus, at least down to the Third Reform Act, in 1884, there remained for many people an incentive to claim that their interests in land were freehold. ${ }^{32}$ Further, there was a long-established rule that receipt of alms within a particular period before an election would disqualify one from voting - except for freeholders; and this rule was incorporated in the 1832 Act. $^{33}$

\section{THE LITTLETON RULE TO 1832}

How does all of this relate to the Mexfield rule? In the judgments in Mexfield, the alleged rule is said to be stated in Littleton, above all Coke's commentary on Littleton

\footnotetext{
${ }^{30}$ Anson (n 18) 27-29

${ }^{31} \mathrm{~S}$ Berlinski and T Dewan, 'Did the extension of the franchise increase the Liberal vote in Victorian Britain?' (2010) LSE Political Science and Political Economy Working Paper No 1, 6 and Table 2 $<$ www.lse.ac.uk/government/research/resgroups/PSPE/pdf/PSPE_WP1_10.pdf $>$ accessed 9 March 2014.

32 cf Wolferstan (n 21) 9

33 ibid 47, 179-180.
} 
at paragraph $42 \mathrm{a}$ ('Co Litt $42 \mathrm{a}$ '). ${ }^{34}$ But, as Low pointed out, the rule as stated in Mexfield omits a crucial part of the rule as stated in Littleton and Coke ('the Littleton rule'): a tenancy expressed to determine only on the occurrence of an uncertain event was deemed to be a determinable life tenancy, and therefore a freehold, only if livery of seisin or a deed had been used. ${ }^{35}$

Livery of seisin is mentioned only once by the Supreme Court in Mexfield and is treated as insignificant, a formalities requirement which was not part of the core Littleton rule. ${ }^{36}$ On the contrary, the requirement was a necessary part of the rule, because livery of seisin demonstrated the intention to create a freehold. ${ }^{37}$ To understand that intention, we must return to the fact that, before 1925, it could include the intention to create a lease for life (or lives). For us, an intention to create a freehold necessarily excludes any intention to create a lease, because, for us, the conceptual divide between freehold and leasehold is absolute; in the past, it was perfectly possible to speak of a 'freehold lease'. ${ }^{38}$ Life tenancies pre-dated both the fee simple and the term of years, and the law's treatment of them was rooted in 'memory of a time when all the military fiefs had been little more than life tenancies'. 39

The consequence of this history was that the opposite of a freehold was a tenancy at will. Maitland describes the concept of freehold as arising from the contrast with unfree, or villein, tenure: a tenant whose obligations were not clearly specified was unfree, because he was subject to the will of his lord. ${ }^{40}$ This fundamental distinction was incorporated in the Littleton rule: if a tenancy or other interest was

\footnotetext{
${ }^{34}$ Mexfield (n 1) 958E, [25], [39]-[40], [44], [48].

${ }^{35}$ Low (n 1) 406.

${ }^{36}$ Mexfield (n 1) [25], [41], [93].

${ }^{37}$ cf Low (n 1) 406-407

${ }^{38}$ eg Philpotts $v$ James (1784) 3 Doug 425. This is, with respect, where Low falls into error, eg ibid.

${ }^{39}$ AWB Simpson, A History of the Land Law (2nd edn, Clarendon Press 1986) 73, cf 49-51, 70-71.

${ }^{40}$ Maitland (n 8) 35-36.
} 
expressed to terminate only on the occurrence of an uncertain event and there was no livery of seisin nor deed, there was merely a tenancy or interest at will. ${ }^{41}$ This is, again, a feature of the Littleton rule which the Supreme Court in Mexfield mentions only once and in passing; ${ }^{42}$ yet it is this 'flip side' of the Littleton rule which turns out to determine the course of the rule's evolution.

Littleton's Tenures was first published in $1481 .^{43}$ At that time livery of seisin was required in order to grant or convey a corporeal freehold and, conversely, had no other use or meaning. It was an 'overt ceremony' consisting of acts and words done and said in a particular place. ${ }^{44}$ If this ceremony was used, demonstrating the intention to create a freehold, but the grantor did not make clear whether his intention was to grant a fee simple, a fee tail, or a life tenancy — the three types of freehold - it was reasonable to assume an intention to grant the smallest freehold, a tenancy for the life of the grantee. So, if there was livery of seisin but the grantor said only that the grant would end on the occurrence of an uncertain event, the law assumed the intention to grant a tenancy for life, determinable on the event.

This sounds like a simple, 'certain' rule, and it would have been, if there had been a fixed form of livery of seisin; but there was not. The matter was simple enough if one party said to the other, 'Here I deliver you seisin and possession of this house'; but what if the words said were 'Enter into this house, and God give you joy of it'? ${ }^{45}$ These and other ambiguous words and acts were in particular cases held to constitute livery of seisin. This was a jury question, and in such cases the jury will have had to decide, by interpretation in all the circumstances, whether there had been an intention

\footnotetext{
${ }^{41}$ eg The Bishop of Bath's Case (1605) 6 Co Rep 34b, 35b.

${ }^{42}$ Mexfield (n 1) [25].

${ }^{43}$ JH Baker, 'Littleton, Sir Thomas (d 1481)', Oxford Dictionary of National Biography (2007) $<$ www.oxforddnb.com/view/article/16787> accessed 22 February 2014.

${ }^{44}$ W Sheppard, The Touchstone of Common Assurances, vol 1 (8th edn, Samuel Brooke 1826) 209

45 ibid 214
} 
to grant a freehold, in order to decide whether there had been livery of seisin; ${ }^{46}$ scratch the surface, and livery of seisin turns out to be less a formalities requirement in the modern sense than shorthand for a finding of 'objective intention'.

As for incorporeal freeholds, it had always been possible to grant or convey these by deed, and the law eventually evolved to allow the same for corporeal freeholds. ${ }^{47}$ Use of a deed made it easy to apply the Littleton rule, given the rule's flip side: one can just about imagine saying 'Enter into this house, and God give you joy of it' even to an intended tenant at will, but no one would use a deed to create a tenancy at will.

However, a difficulty for the Littleton rule arose when an 'equitable freehold' became a qualification for the vote. By the Parliamentary Elections Act 1695, trustees and mortgagees were disqualified from voting unless they were 'in actual possession or receipt of the rents and profits', and, conversely, 'the mortgagor or cestui que trust in possession ... may vote ... notwithstanding such mortgage or trust'; this wording was essentially repeated as s.23 of the 1832 Act. $^{48}$

This was unproblematic where, for example, the terms of a trust expressly gave a beneficiary a life tenancy, even if determinable: that was plainly the equitable equivalent of a legal freehold. But, if the terms of the trust created an interest expressed only to terminate on an uncertain event, it was unclear whether one could apply the Littleton rule at all or, if so, how_-given that, on the face of it, the rule appeared to require the formalities necessary to create a legal freehold. There were two obvious possibilities. One was to convert the Littleton rule into the Mexfield rule, at least for trusts: where the interest was expressed to terminate only on an uncertain event, it could be deemed to be a determinable life interest, with no further

\footnotetext{
46 ibid 209.

${ }^{47}$ Co Litt 42a; Sheppard (n 45) 213; Low (n 1$) 406$

${ }^{48}$ Wolferstan (n 21) 31
} 
requirement - in particular, no matter what the parties could reasonably be held to have intended. Alternatively, one could expose and use the underlying principle of the Littleton rule, interpreting the documents creating the interest to decide the intention; and one could do that in a more or a less restrictive way, either insisting on a clear intention to create a determinable life interest or merely requiring that there be no clear intention that the interest be terminable at the grantor's will.

The question was eventually resolved in favour of the second option, and in its less restrictive version - but only through a debate started by James Manning, who proposed and promoted an extreme version of the first option, purportedly backed by a formidable array of ancient sources.

\section{JAMES MANNING}

In order to understand why Manning proposed the sort of rule he did, and how he came to be in a position to promote it so effectively, we need to consider his background, and what it meant in terms of his place in legal society and political culture.

Manning was born in 1781, the son of a Unitarian minister in Exeter; he was called to the Bar at Lincoln's Inn in 1817, but had already 'acquired an early familiarity with history, antiquities, and European languages. ${ }^{49}$ Pollock described Manning as the 'one man' who more than any other 'revived the study of' the Year Books, the closest thing we have to case reports before the mid-sixteenth century. ${ }^{50}$ By 1821, Manning's historical expertise was sufficiently well known for the Inner

\footnotetext{
${ }^{49}$ GC Boase, rev E Metcalfe, 'Manning, James (1781-1866)', Oxford Dictionary of National Biography (2004) <www.oxforddnb.com/view/article/17971> accessed 22 February 2014.

${ }^{50}$ F Pollock, 'Introduction', in WC Bolland, The Year Books (CUP 1921) ix.
} 
Temple to commission him, and pay him handsomely, to translate a number of their manuscript Year Books from medieval 'law French' into English. ${ }^{51}$

At the same time, he rapidly established himself as a barrister: by 1820 , he was assisting Henry Brougham in the defence of Queen Caroline, arguably the most high-profile political event of the early nineteenth century. ${ }^{52} \mathrm{He}$ then became a serjeant ${ }^{53}$ and sat as a Recorder for many years. ${ }^{54}$ He also became a member of two influential organisations set up by Brougham, the Society for the Diffusion of Useful Knowledge $^{55}$ and the Law Amendment Society. ${ }^{56}$ Finally, from 1828 to 1857 , Manning was the editor of three series of case reports in succession; ${ }^{57}$ as was not uncommon in this period, his reports often have footnotes containing commentary.

So, by 1832, Manning was well regarded as a legal historian and barrister, and was publishing his own views on the law. Further, although he does not appear to have engaged in directly party-political activity, his individual and social connections are characteristic of the history of Liberalism. ${ }^{58}$ Then, in 1832 , he became one of the first revising barristers. ${ }^{59}$

\footnotetext{
${ }^{51}$ Bolland (n 52) 47

${ }^{52}$ Boase rev Metcalfe (n 50); B Hilton, A mad, bad, and dangerous people? England 1783-1846 (Clarendon Press 2006), 269

${ }^{53}$ See W Cornish et al, The Oxford history of the laws of England: Vol XI, 1820-1914 (OUP 2010), 1055-1057

${ }^{54}$ Boase rev Metcalfe (n 50)

${ }^{55} \mathrm{R}$ Ashton, 'Society for the Diffusion of Useful Knowledge (act 1826-1846)', Oxford Dictionary of National Biography (2013) <www.oxforddnb.com/view/theme/59807> accessed 22 February 2014. For a list of members of the Society's committee, see an anonymous publication of the Society, The Rights of Industry: Addressed to the Working-Men of the United Kingdom (Charles Knight 1831) 2.

${ }^{56}$ G Sutherland, 'Manning, (Elizabeth) Adelaide (1828-1905)', Oxford Dictionary of National Biography (2007) <www.oxforddnb.com/view/article/48451> accessed 22 February 2014; L Goldman, Science, Reform, and Politics in Victorian Britain: the Social Science Association, 1857-1886 (CUP 2002) 33-58

${ }^{57}$ GC Boase, 'Manning, James', in S Lee (ed) Dictionary of National Biography (vol 36, Smith Elder \& Co 1893) 69.

${ }^{58}$ See ns 56 and 57 above; and Hilton (n 52) eg index entries for Unitarianism, Brougham, Caroline, the SDUK.

${ }^{59}$ Anon, 'Review: Notes of Proceedings in Courts of Revision held in October and November 1832, before James Manning, Esquire, Revising Barrister. And the Reform Act, with Explanatory Remarks. By William M Manning', (1833) 5 The Legal Observer 217.
} 


\section{THE MANNING RULE}

It seems that Manning became interested in the Littleton rule sometime between 1832 and 1838 , and that his proposed variation of it first appeared in print in 1838, in a law journal called The Jurist.

\section{The Jurist (1838)}

By way of introduction, the journal said only, 'The following is a Decision by $\mathrm{Mr}$ Manning at the last Revision for South Hants. ${ }^{, 60}$ The decision regarded an objection to the registration of George Silly (sic), whose qualification was described as 'minister for life of the freehold independent chapel. ${ }^{61}$ Manning begins by saying that Mr Silly was appointed by 'the ordinary mode':

'by a letter of invitation ... [which was,] as usual, wholly silent as to the period during which this gentleman's ministry was to be exercised. ... In these cases I have been in the habit of inquiring whether, at the time of the invitation, the parties ... understood the engagement to be for life ... Upon further consideration, however, I think that such an inquiry is as unnecessary as it is commonly found to be unsatisfactory; and I am of opinion, that wherever ... property is held upon trust to pay over the rents and profits to the minister, the latter is entitled to be registered as a voter. ${ }^{62}$

\footnotetext{
${ }^{60}$ Anon, 'Elective franchise of dissenting ministers' (1838) 2 The Jurist 459, 459 col 1.

61 ibid.

62 ibid.
} 
It is thus obvious that Manning had dealt with a number of similar cases before as a revising barrister, and had been asking his own questions on the basis of his own legal analysis, and that his initial reflex had been an analysis focused on intention, albeit subjective intention.

It was 'necessary to examine the claim upon general legal principles' because 'the decisions of committees of the House of Commons which bear upon this point are not uniform, nor are the grounds of those decisions always very intelligible. ${ }^{, 63}$ Manning notes that, by statute, both legal and equitable freehold interests in land can confer the vote. He then asserts that, if a minister had an interest in land conveyed to him for so long as he remained minister, he would have an estate for life and therefore a legal freehold 'even if it had been expressly stipulated that the minister should be removable - at the will of ... the church' ${ }^{64}$ To support this last, rather startling, assertion, Manning puts together, on the one hand, Co Litt $42 \mathrm{a}$ and a number of similar sources ${ }^{65}$ _including some cited in Mexfield 173 years later, but not the one judgment relied on in Mexfield which would have been available to him ${ }^{66}$ - and, on the other hand, a statement by Brudnell CJ in the Year Books saying that a lease 'at the will of the lessor ... is a lease for life. ${ }^{67}$

As Manning must have known from translating them, the Year Books do not contain reports of judgments; they consist of notes of discussion during hearings. JH Baker emphasised that we cannot 'confidently tell which of the jotted remarks were intended or thought to lay down the law, which merely to provoke a response, or even, perhaps, calculated to make things sufficiently unclear to alarm the parties into a

\footnotetext{
63 ibid.

${ }^{64}$ ibid.

65 ibid.

${ }^{66}$ Doe d Warner v Browne (1807) 8 East 165; see Mexfield (n 1) [29]-[30] and [41].

${ }^{67}$ Anon, 'Elective franchise of dissenting ministers' (n 61) 459 col 2
} 
compromise'. ${ }^{68}$ During a hearing, judges might even advance an argument for intellectual entertainment, or at least be suspected of it - in a hearing in 1522, Broke $\mathrm{J}$ is recorded as saying to Brudenell (Manning's 'Brudnell') CJ, 'truly you have made a good case out of this, but I think you have been arguing mainly for your pleasure' ${ }^{69}$ Further, individual copies of the Year Books are notoriously unreliable: Baker quotes Maitland lamenting 'the hopeless mass of corruption that passes as a text of the year books'. ${ }^{70}$ Nonetheless, Manning presents statements from the Year Books as though they were said as ratio and in a reliable transcript of judgment.

Manning mentions that the Littleton rule turns a tenancy expressed to determine solely on the occurrence of an uncertain event into a tenancy for life only 'if livery be made' or a deed is used, and that otherwise the estate or interest is only 'at will'; but he asserts that the trustee's legal seisin of the trust property is per se 'the equitable seisin' of the beneficiary in his interest under the trust. ${ }^{71}$ He then repeats his proposed rule:

'a dissenting minister has an equitable freehold ... in all those cases in which the legal freehold is held in trust, to pay the rents to the minister, such equitable freehold being - defeasible, if the appointment be held subject to a power of dismissal-absolute, if it be not so subject; the interest being, in either case, sufficient to support the elective franchise. ${ }^{72}$

\footnotetext{
${ }^{68}$ JH Baker, 'Why the History of English Law Has Not Been Finished' [2000] CLJ 62, 67.

${ }^{69}$ Gervys v Cooke (1522), in JH Baker (ed) Year Books of Henry VIII, 12-14 Henry VIII 1520-1523

(119 Selden Society 2002), 122. Some barristers may feel that little has changed.

${ }^{70}$ Quoted in Baker, 'Why the History of English Law Has Not Been Finished' (n 69) 64.

${ }^{71}$ Anon, 'Elective Franchise of Dissenting Ministers' (n 61) 459 col 1-2.

72 ibid 460 col 1.
} 
Manning accepts that his rule might be 'considered by some persons' to be 'negatived' by two comparatively recent judgments, Doe d Jones $v$ Jones ${ }^{73}$ and Doed Nicholl v M'Kaeg. ${ }^{74}$ These held that 'the trustees of ... lands of which they are seised in trust for the support of the minister' could evict the minister 'upon a simple demand of possession, without any notice to quit'. ${ }^{75}$ Manning's response is that even if, in law, there is a tenancy at will, there is still an equitable freehold for electoral purposes. ${ }^{76}$

This first version of Manning's proposed rule is therefore much narrower than the Mexfield rule in applying only where there is an express trust. But it seems in another sense much broader: the Supreme Court in Mexfield did not go so far as to say that its rule would convert into a determinable life tenancy even a tenancy expressly terminable at the mere will of the landlord. Then again, in modern English law, it is hard to imagine any practical difference between a tenancy at will and a tenancy for life subject to determination at the landlord's will. A difference could however arise in the context of nineteenth-century property qualifications.

Finally, Manning's decision in the case before him is illuminating:

'the building appears to be the private property of fourteen persons, who hold it subject to no trust, and who allow it to be used as a place of worship, merely because, and so long as, they think it proper to do so. ... [T]herefore, the respondent ... has no estate or interest, legal or equitable, in the chapel or building in respect of which he has claimed. His name must, therefore, be expunged. ${ }^{77}$

\footnotetext{
73 (1830) 10 Barn \& Cress 718

${ }^{74}$ (1830) 10 Barn \& Cress 724; Anon, 'Elective Franchise of Dissenting Ministers' (n 61) 460 col 1.

${ }^{75}$ Anon, 'Elective Franchise of Dissenting Ministers' (n 61) 460 col 1.

76 ibid.

${ }^{77}$ ibid 460 col 2.
} 
Manning's lengthy reasoning and scholarship were therefore unnecessary to his decision; he plainly wanted to get his proposed rule into the public domain for its own sake.

\section{Hayes on Conveyancing (1840)}

Two years later, Manning's proposed rule was published in a popular land-law textbook, 'Hayes on Conveyancing'. In the fifth edition, Hayes inserted nearly the whole of Manning's 1838 judgment as a footnote running to nearly five pages. ${ }^{78}$ Hayes introduces it by saying, 'The following extract from a decision by Mr Manning (Recorder of Oxford, and Revising Barrister for South Hants) ... will throw some light upon the legal character and nature of freehold interests. ${ }^{, 79}$

What follows has not, however, simply been extracted from The Jurist. There are more cases cited; in particular, a second statement in the Year Books, from Brian $\mathrm{CJ}$, is quoted as supporting the statement by Brudnell $\mathrm{CJ}{ }^{80}$ There is the same assertion as in the Jurist version, that '[i]n the case of equitable interests, the legal seisin of the trustee, whether acquired by livery or otherwise, is the equitable seisin of the cestui que trust', but the Hayes version inserts a reference, 'Co Litt 42, note 10. ${ }^{, 81}$ The Hayes version then puts the proposed rule in capitals for emphasis. ${ }^{82}$ Finally, the Hayes version both starts and ends by citing Littleton and Coke on Littleton; ${ }^{83}$ and, as already noted, Hayes tells his general land-law readers that this decision illuminates the nature of freehold interests generally, not only for electoral purposes.

\footnotetext{
${ }^{78}$ W Hayes, An Introduction to Conveyancing, vol 2 (5th edn, S Sweet 1840) 38-43.

${ }^{79}$ ibid 38 (emphasis in original).

${ }^{80}$ ibid 40.

${ }^{81}$ ibid 39-40.

${ }^{82}$ ibid 42.

${ }^{83}$ ibid 43, citing Littleton, sect 350, and Co Litt 214b, 218 a.
} 


\section{Wynne v Wynne (1840) 2 M\&G 8}

Later the same year, Manning published this argument in his own series of case reports, albeit in much shorter form, in his report of Wynne $v$ Wynne. ${ }^{84}$ This was not a registration case but rather involved married women's property. As with the 1838 judgment, it was not necessary to have any discussion of the Littleton rule or Manning's variation: the dispute concerned Sarah Wynne's rent-charge, which under the terms of the relevant trust was expressly for life unless a particular event happened (which was not the mere will of the trustees). ${ }^{85}$ Manning nonetheless makes the argument in the case report in a footnote.

As already noted, in the usual practical sense of resisting eviction, there would be no point in a rule converting a tenancy at will to a tenancy for life determinable at the grantor's will. In Manning's time, though, there would be a point, for a man, in terms of his ability to vote and, for a married woman, in terms of her control over property. Down to the late nineteenth century, a married woman's personal property became, in law, her husband's absolutely, whereas her real property vested in her and her husband jointly during the marriage. A life interest, even if determinable, was a freehold, and freeholds were classically real property, whereas leaseholds, let alone tenancies at will, were and technically still are personal property. ${ }^{86}$

For current purposes, what is salient is that, in his footnote to Wynne, Manning appears to assert the Mexfield rule per se: 'any interest in land of uncertain duration (though not expressed to be for life), determinable by matter subsequent ..., constitutes

\footnotetext{
${ }^{84}(1840) 2$ M\&G 8.

85 ibid 9.

${ }^{86} \mathrm{JH}$ Baker, An Introduction to English Legal History (4th edn, Butterworths 2002) 485; S Bridge, M

Dixon, and C Harpum, Megarry \& Wade: the Law of Real Property (8th edn, Sweet \& Maxwell 2012) [1-011].
} 
a freehold for life', ${ }^{87}$ with no mention of any difference between legal and equitable interests. He then gives references to 12 textbooks - including Co Litt 42a, and the volume and page in Hayes containing Manning's own judgment - and 25 cases, largely from the Year Books.

\section{THE COURT'S RESPONSE}

When, after the 1843 Act, disputes concerning property qualifications for the vote finally came to court, Manning's argument was picked up and used by other barristers. Understanding the court's response requires some further historical context.

First, registration disputes had become fiercely party-political. After 1832, local party organisations were rapidly established to get party supporters or potential supporters to register-and to lodge objections to actual or suspected opponents; ${ }^{88}$ in due course, the political 'parties themselves took on responsibility for defending the votes of their own supporters' against objections. ${ }^{89}$ Every judge hearing registration appeals must have been aware of this background. Moreover, from the 1840 s down to 1867, there was constant controversy over further extension of the franchise-but controversy which was obsessed with details. Most MPs agreed that there should be further reform, but there was ever-increasing awareness that the details of how the franchise was extended could have consequences which were not immediately obvious and might be enormous. ${ }^{90}$ Again, judges must have been aware of the risks involved in destabilising the fundamental land-law terms of this party-political debate and of the existing franchise.

\footnotetext{
${ }^{87}$ Wynne (n 85) 19.

${ }^{88}$ Salmon (n 24) 11, 27-29, 34, 40.

${ }^{89}$ ibid 34.

${ }^{90}$ R Saunders, Democracy and the Vote in British Politics, 1848-67 (Ashgate 2011) eg 7-9, 118-130.
} 
At the same time, judges were, consciously or unconsciously, working within a framework of ideas in which there were not only, as described earlier, two views of the purpose of property qualifications but also more broadly two different views of the constitution. Crudely summarising one aspect of a complex and extensive literature: in one view, what made the British constitution "the "most perfect" ever devised"91 was that it was 'organic' and had always evolved; in another, there was an ancient 'true' constitution which had been suppressed. To the extent that these views mapped onto party politics at all, it was radicals who were most likely to appeal to the idea of reviving an ancient constitution. ${ }^{92}$

On 21 November 1844, the Court of Common Pleas handed down two decisions which would go on to be commonly cited in later registration appeals. The same judges - Tindal CJ and Coltman, Maule, and Erle JJ-heard both appeals, and both concerned similar facts. Yet, in Davis $v$ Waddington, ${ }^{93}$ the would-be voters lost, whereas in Simpson $v$ Wilkinson ${ }^{94}$ the would-be voters won.

\section{Davis v Waddington (1844) 7 M\&G 37}

In Davis, the 25 appellants were inhabitants of Jesus Hospital—what we would call an almshouse - founded in 1597 to provide for 'poor and infirm men'. ${ }^{95}$ Its charter, in Latin, gave its governors the power 'to elect' but also to 'expel' its principal or any of

\footnotetext{
91 ibid 3.

${ }^{92}$ See eg ibid 3-6; B Weinstein, "Local Self-Government Is True Socialism”: Joshua Toulmin Smith, the State and Character Formation' [2008] EHR 1193; DR Kelley, 'Historians and Lawyers', in G Stedman Jones and G Claeys (eds), The Cambridge History of Nineteenth-Century Political Thought (CUP 2011); J Greenberg and M Sechler, 'Constitutionalism Ancient and Early Modern: the Contributions of Roman Law, Canon Law, and English Common Law’ [2013] Cardozo LR 1021; and, generally, J Vernon (ed), Re-reading the Constitution (CUP 1996).

93 (1844) 7 M\&G 37

${ }^{94}$ (1844) 7 M\&G 50

${ }^{95}$ Davis (n 94) 38.
} 
its 24 inmates, who were to hold their positions in the hospital 'for the time being, ... as it shall seem to be convenient [conveniens] to' the governors. ${ }^{96}$

Despite these provisions, '[n]o instance is recorded of any principal or inmate having been expelled from the hospital'; new inmates were only appointed when an existing inmate died. ${ }^{97}$ 'The principal has a house and garden within the hospital, and each inmate, on his appointment, is provided with a room and piece of ground, for his own separate use, of the value of more than 40 s. per annum' ${ }^{98}$ All of them claimed the vote as freeholders; Mr Waddington had objected, on the grounds that 'the power of amotion by the governors ... prevented [the principal and inmates] from acquiring any estate of freehold'; and the revising barrister had upheld the objection. ${ }^{99}$

Counsel for the appellants relied first on the construction of the charter, submitting that, in the Elizabethan period, the meaning of 'conveniens' was such that the principal and inmates could only be evicted for misconduct. Therefore, counsel argued, this was 'an estate during good behaviour, [and thus] ... equivalent to an estate for life ... since it must be by [the grantee's] own act ... that his estate can determine." ${ }^{100}$ Counsel for the respondent submitted simply that ' $[t]$ he inmates have not an estate for life' because '[t]hey may be removed by the governors whenever it shall seem convenient to them'. He added, significantly, 'They hold their situations upon the same tenure as the king's judges did before the Revolution, who were appointed durante bene placito nostro [during his Majesty's pleasure]. ${ }^{101}$ In reply, counsel for the appellants fell back on Manning: 'At any rate, this is an interest of uncertain duration, and consequently it constitutes a tenancy for life. This rule is laid

\footnotetext{
${ }^{96}$ ibid 39.

${ }^{97}$ ibid 38.

${ }^{98}$ ibid 38.

99 ibid 40-41.

100 ibid 41-42.

101 ibid 42-43
} 
down as collected from the ancient authorities, in a note to Wynne v. Wynne; and is also to be found in Co. Litt. 42 a., ${ }^{102}$

The court however dismissed the appeal, in short judgments. They relied solely on the construction of the charter, which made the principal and inmates 'subject to removal at the arbitrary discretion' of the governors. They dismissed the idea that such an interest could be deemed to be a tenancy for life without even mentioning, let alone discussing, Manning's note to Wynne or any of his sources, including Co Litt 42a. ${ }^{103}$

Manning's response was to insert a 2,400-word footnote to his report of Davis, drawing on material from his 1838 judgment and his note to Wynne. He asserted that the judgments in Davis contradicted a 'long and unbroken series of decisions' that even 'an absolute power ... [of a grantor] to remove [a grantee] at pleasure' was not 'inconsistent with the existence of a freehold interest'; ${ }^{104}$ if an office or appointment under a trust carried with it an interest in land, that interest was a life interest even 'if the office or appointment was determinable ... at the mere will of ... the trustee., ${ }^{, 105}$ The key steps and sources for the argument remained the same: first Co Litt 42a, ${ }^{106}$ then the statements by Brudnell $\mathrm{CJ}^{107}$ and Brian $\mathrm{CJ},{ }^{108}$ and finally the assertion that livery or a deed is not necessary for an equitable freehold. ${ }^{109}$

\section{Simpson v Wilkinson (1844) 7 M\&G 50}

\footnotetext{
102 ibid 43

103 ibid 45

${ }^{104}$ ibid 45 n 5

105 ibid 49

${ }^{106}$ ibid 45-46

${ }^{107}$ ibid 46.

108 ibid 47.

${ }^{109}$ ibid 47-48.
} 
In Simpson, an objection had been made to the registration of the inmates of Lord Burghley's Hospital, founded to provide for 'thirteen poor men' who had 'by sickness or any other impediment' become 'unable to get their livings'. 110 'Each bedesman keeps the key of his room', and each room had an annual value of $£ 4 .{ }^{111}$ There was 'no trace of ... any charter [or] deed' founding the hospital, ${ }^{112}$ but there was a copy of what were thought to be its original rules, stated to be made by Lord Burghley. Reprinted apparently in full in the report, there was a long list of rules, some of them very odd, and a statement that inmates could be removed for breach, but no express statement either that the 'bedesmen' were appointed for life, or for a particular term, or that they were removable at anyone's will. ${ }^{113}$ As in Davis, '[n]o person appointed ... as a bedesman, has ever been known to be removed during his life. ${ }^{114}$ Lord Burghley's heirs, by this time Lord Exeter, appeared to remain the 'owner' of the hospital. ${ }^{115}$

The objection had been on a number of grounds, including '[t]hat if the claimants had any freehold estate,' it was 'only as members of a corporation aggregate' - it was settled law that, if a corporation aggregate held a qualifying interest, that did not confer a vote on the corporation's members. ${ }^{116}$ The revising barrister had rejected all of these arguments, holding 'that, under the circumstances, a legal foundation might be presumed, not necessarily investing the claimants with a corporate character, and that they were respectively entitled to a separate freehold estate in their respective rooms. ${ }^{117}$

\footnotetext{
${ }^{110}$ Simpson (n 95) 53, 56[10]-57[11].

111 ibid 51.

112 ibid 51-52.

113 ibid 53-61.

114 ibid 51.

115 ibid 52, 53[1].

116 ibid 52; Wolferstan (n 21) 29.

${ }^{117}$ Simpson (n 95) 53.
} 
Counsel for the appellant attempted to argue that either the hospital was a corporation aggregate, such that the bedesmen were unqualified to vote, or 'it is a mere gratuitous act on the part of Lord Exeter to continue the charity; and consequently the bedesmen have no rights conferred upon them. ${ }^{, 18}$ Counsel then argued that some of the rules for breach of which a bedesman could be removed were so 'very singular' as to be tantamount to a power to remove at will. ${ }^{119}$ Finally, he tried to raise an additional objection, that providing these men with accommodation was in itself a giving of alms, such as to disqualify them from voting; but this submission was ended by Erle J saying, 'Was there ever a case in which an estate for life in lands, was considered to be alms? ${ }^{, 120}$

Counsel for the respondents said only that the revising barrister's finding that the hospital was a foundation by royal licence rather than incorporation was 'an inference of fact ... in respect of which there can be no appeal. He was then stopped by the court. ${ }^{, 121}$ The court swiftly and shortly dismissed the appeal. Maule J, whose judgment of seven sentences is the longest of the four, said: 'We may fairly presume that the hospital was endowed by a licence from the Crown. ... The only question in the case is, whether these bedesmen have an equitable estate. I think they have; as they are not liable to arbitrary amotion. ${ }^{, 122}$

Manning's report of Simpson follows his report of Davis in the same volume, so there is only a short footnote: 'Upon the question, whether the existence of an arbitrary power determining the interest will derogate from the freehold character of

\footnotetext{
118 ibid 62.

119 ibid 63.

${ }^{120}$ ibid 63-64; cf Fryer v Bodenham (1869) LR 4 CP 529.

${ }^{121}$ Simpson (n 95) 64

122 ibid 65.
} 
such interest as a legal life estate, see [Brudnell CJ, Brian CJ, and] Co Litt. 42 a. As to equitable interests, vide ante [his note to Davis]. ${ }^{, 123}$

\section{Beeson v Burton (1852) 12 CB 647}

In the next eight years, a number of judgments followed the pattern established by Davis and Simpson, with similar results on similar reasoning, taking no account of Manning's argument or his sources. ${ }^{124}$ Those sources were finally addressed in Beeson v Burton. ${ }^{125}$

Before and after the 1832 Act, men with interests in property within a borough which would qualify them to vote in the surrounding county could vote in the county. ${ }^{126}$ In the borough of Leicester, in 1845 , a private Act of Parliament, $8 \& 9$ Vict. c. 6, had made provisions for allotments. Under this Act, the resident freemen of Leicester elected deputies in whom the allotment land was vested on trust for the resident freemen. By s.17, the deputies had a power of sale, which, by s.22, was exercisable only with the consent of the majority of the resident freemen. There was no express provision that the allotments were to be held either for any particular term or for life subject to earlier termination; the Act said only, at s.8, that the allotments were

'to be held respectively by each resident freeman desiring to become the occupier, and obtaining possession thereof, so long as he shall be willing to

\footnotetext{
123 ibid 65 n 7.

124 eg Ashmore v Lees (1845) 2 CB 31, Burton v Brooks (1851) 11 CB 41.

125 (1852) 12 CB 647

${ }^{126}$ Wolferstan (n 21) 45-46.
} 
hold the same, and shall pay the annual rent, and conform to the orders and regulations to be made from time to time by the said deputies',

with the deputies having a power of re-entry for non-payment of rent or other breach. ${ }^{127}$ Mr Burton and 28 others held allotments with a value above 40s per annum and had registered to vote in Leicestershire as freeholders; Mr Beeson had objected, the revising barrister had dismissed the objections, and Mr Beeson appealed. ${ }^{128}$

Counsel for the appellant pointed out that the revising barrister had relied on Davis and Simpson, and that the ratio of Davis was that the claimants in that case were 'not entitled to be registered as freeholders' because 'the trustees had power to remove the inmates at their pleasure.' He submitted that similarly, in the present case, the deputies' power of sale enabled them to terminate the respondents' interests, so the respondents had only a 'tenancy at will' and could not have a freehold: 'It is of the very essence of a freehold, that it should be held without being subject to the will of anybody. $^{, 129}$

Counsel for the respondents first submitted that 'the 11th section [of the Act] obviously contemplates the death of the occupier as the ordinary determination of his estate'; that section is neither quoted nor described in the report, but it was not in the event relied on by the court. His main argument expressly relied on 'Serjeant Manning's ... very learned' notes to Wynne and Davis - but only for Manning's sources; Manning's interpretation of them was not mentioned. ${ }^{130}$ Instead, counsel interpreted the sources (excluding the statements of Brudnell and Brian CJJ, which

\footnotetext{
${ }^{127}$ Beeson (n 126) 648, cf 647-649.

128 ibid 649, 647.

129 ibid 655 .

130 ibid 656-657.
} 
were also not mentioned), as supporting the court's decisions and reasoning from Davis and Simpson on:

'The result of the authorities referred to in that note [to Davis], is, that, where the interest is determinable at the will of the grantor, it is a mere estate at will; but, where it is made to depend upon the will of the grantee, or the uncertain act of a stranger, the law considers it as an estate for life. That is in conformity with the rule laid down in Co. Litt. 42 a. ... Here, there is an uncertain event which may put an end to the estate, viz. a sale of the land; but ... the act expressly provides that that shall only take place with the consent of the majority of the resident freemen,- - which practically is, with the consent of the occupier himself' ${ }^{131}$

The court unanimously dismissed the appeal — and, for the first time in this line of authority, considered the ancient sources.

Jervis CJ and Maule and Williams $\mathrm{JJ}$ gave separate judgments (Talfourd $\mathrm{J}$ merely concurred), but all in the same terms, focused on interpreting the 1845 Act, and all with reference to 'the older cases.' ${ }^{132}$ Jervis CJ gave the most detailed judgment, largely repeating the main submission of counsel for the respondents: s. 8 meant that the allottee might hold an allotment for life, and ss.17 and 22 meant that this interest could not be terminated by the deputies at will. Therefore, the case 'falls within the definition of an estate for life in Co Litt 42a. ${ }^{133} \mathrm{He}$ also emphasised that there should be no separate electoral version of land law:

\footnotetext{
131 ibid 657.

132 ibid 660 .

133 ibid 658-659.
} 
'If this is not a freehold, what estate is it? It clearly is not an estate for years: nor is it an estate at the absolute and uncontrolled will of the lessors. It is suggested that it is a sort of parliamentary estate, floating between an estate of freehold and an estate at will. It would manifestly be very inconvenient so to hold; and I do not see how we can consistently with the rules of law hold this to be any other than an estate of freehold. ${ }^{, 134}$

Maule J spelled the matter out simply:

'It is well established that an estate which may last for a man's life is, ordinarily, a freehold. ... An estate determinable on a condition, which condition cannot arise at the absolute will of the lord, is a freehold. Here, ... the estate is capable of being determined upon ... an event which is not dependent on the will of the lord. ... [This] is clearly such an estate as according to the older authorities is an estate of freehold.'

He too emphasised that this conformed to 'the general law'. ${ }^{135}$

Williams J said only: 'This is clearly an estate of freehold, inasmuch as it is for an uncertain interest, which may last for the life of the party, and is not confined to the will of the grantors. It comes, therefore, within the examples given in some of the older cases. ${ }^{, 136}$

Thus, in Beeson, the court used the very sources which had been brought back to light by Manning, particularly Co Litt 42a, to support the approach the court had already settled on, focused on construing the relevant documents. Further, the court

\footnotetext{
134 ibid 658-659.

135 ibid 659-660.

136 ibid 660 .
} 
did not draw any distinction between legal and equitable freeholds. For legal freeholds, this meant substituting, for the Littleton rule per se, interpretation on the basis of the principle underlying that rule.

This development of the law, in a fraught party-political context, was supported by the framework of constitutional ideas. Manning's approach directly contradicted the Blackstonian justification for property qualifications, while also being reminiscent of appeals to 'the ancient constitution' in purporting to resurrect ancient rules and denounce deviation from them. ${ }^{137}$ The court's approach, by contrast, incorporated the Blackstonian principle underlying property qualifications - those with property (even under a charitable trust) should be represented, unless they were subject to their landlord's will; and, being also clearly derivable from the Littleton rule, the court's approach aligned with the widespread belief that the constitution did and should evolve.

\section{Epilogue: Spencer v Harrison (1879) 5 CPD 97}

From Beeson until at least the 1870s, Manning's notes to Wynne and Davis, and, with them, Co Litt 42a, continued occasionally to be raised in submissions in registration appeals. ${ }^{138}$ But the court did not change its approach; it simply saw less and less need to refer to the ancient sources, as they had been considered and a simple principle extracted from them in Beeson. ${ }^{139}$ It is therefore unsurprising that, by 1903, the Court of Appeal in Zimbler relied on pure construction; by then, this had been established for half a century as the rightful heir to the Littleton rule.

\footnotetext{
${ }^{137}$ See eg J Vernon, 'Notes towards an introduction', in Vernon (n 93).

${ }_{138}$ eg Trenfield v Lowe (1869) Law Rep 4 CP 454, Ashworth v Hopper (1875) 1 CPD 178.

${ }^{139}$ eg Fernie v Scott (1871) 7 CP 202.
} 
As for James Manning, he seems to have turned his attention to another issue, foreshadowed by Wynne. His first wife died in 1847. Manning subsequently became involved in the movement to reform the law on married women's property. In 1857 he remarried, to a widow in her fifties who had recently published a well-regarded study of ancient India. His daughter and his second wife became good friends with each other and with Emily Davies, the future founder of Girton College, Cambridge; and all three were active in particular on issues relating to women and education, with James's assistance until his death in $1866 .^{140}$

After Manning's death, his proposed rule, already buried, got a stake through its heart. In Spencer $v$ Harrison, ${ }^{141}$ it appears that counsel did not raise Manning's argument or the related sources. Nonetheless, Lopes and Lindley JJ expressly considered Manning's notes to Wynne and Davis, and showed that Manning had wrongly interpreted his key Year Book source-the one aspect of Manning's argument which had not previously been dealt with. They then arrived at the same conclusion as in Beeson - that the question was one of the proper interpretation of the agreement, in particular whether it was intended to be terminable at the will of the grantor. $^{142}$

\section{CONCLUSION}

The story of the Manning rule raises more questions than it answers; but three conclusions may be suggested. First, the Supreme Court in Mexfield was, with the greatest respect, wrong in accepting the submission that there had ever been such a

\footnotetext{
${ }^{140}$ Sutherland (n 57); A Murphy and D Raftery (eds) Emily Davies: Collected Letters, 1861-1875 (Univ of Virginia Press 2004) 103, 183-194, 201-203.

141 (1879) 5 CPD 97.

142 ibid 103-104.
} 
thing as the Mexfield rule, and wrong in disapproving Zimbler. The real ratio of Mexfield remains the same: although the court insisted that it preferred to get to the result by the alleged rule, it also held (with the greatest respect, correctly) that the relevant agreement, on ordinary principles of interpretation, was intended to be a determinable life tenancy; and only this reasoning was necessary to reach the result. ${ }^{143}$

Second, in investigating the roots of today's land law, constitutional land law should not be overlooked. Some of the most important debates as to the definition of particular interests in land will have taken place in the context of disputes about property qualifications. If the answer to the puzzle of Mexfield can be found in this forgotten realm, there may be answers to other land-law puzzles in there too.

Finally, in the Manning line of cases, the court rejected a crude allegedly ancient rule in favour of an approach which was principled and fact-sensitive, derived from but not arbitrarily constrained by ancient sources, in a way which reflected a particular set of ideas about the constitution. One might ask what it says about the current court's vision of the constitution that the Supreme Court, in Mexfield, did precisely the reverse.

\footnotetext{
${ }^{143}$ Mexfield (n 1) [44]; Roche (n 1) 444-446, 447-449; cf Secretary of State for Transport v Blake [2013] EWHC 2945 (Ch) [20]-[21].
} 